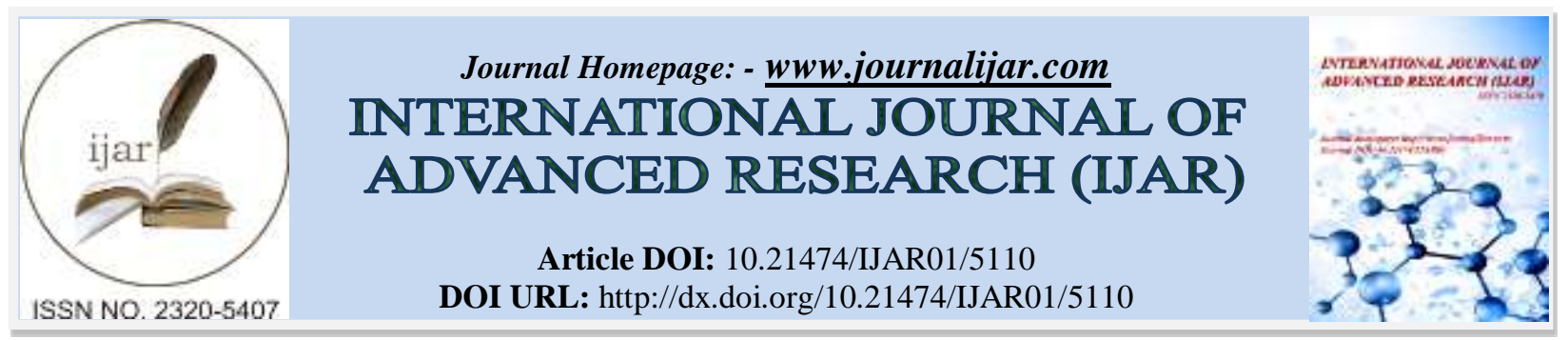

RESEARCH ARTICLE

\title{
BIOSORPTION METHOD AND BIOSORBENTS FOR DYE REMOVAL FROM INDUSTRIAL WASTEWATER: A REVIEW.
}

\author{
Yusuf Alparslan Argun ${ }^{1}$, Ayse Karacali ${ }^{1}$, Ulas Calisir ${ }^{1},{ }^{*}$ Namik Kilinc $^{1}$ and Hakan Irak ${ }^{2}$. \\ 1. Vocational School of Health Service, Department of Medical Services and Techniques, Igdir University, Igdir, \\ Turkey. \\ 2. Vocational School of Igdir, Department of Management and Organization, Igdir University, Igdir, Turkey.
}

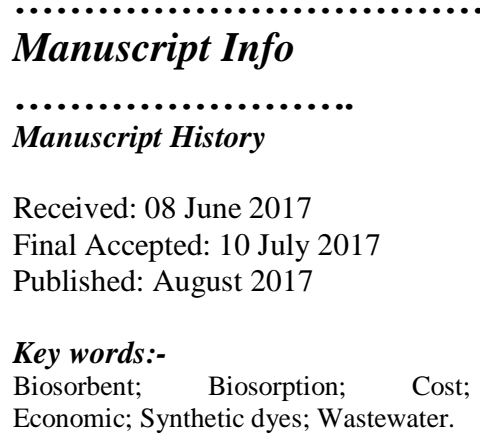

Biosorbent; Biosorption; Cos;
Economic; Synthetic dyes; Wastewater.

\section{Abstract}

Dyes used during various industrial activities in the production of the essential consumer goods, of modern life's, especially such as textiles, leather, cosmetics, food and beverage, paper and pulp mill cause the most important inevitable environmental pollution problems of the contemporary world's, and also threatens the ecological balance. Especially, as a result of the textile wastewaters that contain high amounts of synthetic dyes, light transmission is reduce and the photosynthetic activity of aquatic life is adversely affected, so this situation causes a highly toxic effect on living communities. Although physical and chemical methods are used for the removal of these dyes, alternative methods such as biological systems are needed due to disadvantages like high costly, acting on a limited number of dyes types and disposal of concentrated sludge in large quantities. Biosorption method with low-cost, high metal binding capacity and its feature as microorganisms taking the main role drawn the attention of the scientific world as an alternative method for the removal of industrial waste. Studies in recent year has drawn the attention to the existence of organism which have the ability to remove many types of dyes from wastewater. Bacteria, fungi (mold-yeast and filamentous fungi), algae and seaweeds are group of organisms can be used in this regard.

Trametes versicolor (white rot fungus) which is a filamentous fungus is a species of belonging to Basidiomycetes class, tested in numerous researches as a dyes remover. Rhizopus arrhizus belonging to Zygomycetes class is another fungal species tested as dyes remover. The species that belong Cladophora genus from green algs and bacteria that belong to Bacillus and Pseudomonas genus are between microorganisms group that can be used as biosorbent. This study is aimed to provide an overview to the microorganism used in biosorption method and collect latest information about the subject. The first economic feasibility studies on applicability of biosorption technology show that this process provides significantly cost savings and that the recovery of heavy metals reduces additional cost. 


\section{Introduction:-}

Water resources have critical importance for both ecosystem and human development. The rise in environmental pollution based on industrial wastewater has created a major concern in developing countries and the importance of water pollution control has been increasing steadily in recent years. Despite the fact that dye substances, which are released into the environment, constitute a small portion of water pollution; the presence of dyes in the receiving environment is an undesirable situation in terms of aesthetics even if they are in very low concentrations. Furthermore, the dyed wastewater, which is released into receiving waters, reduces the light transmission of the aquatic environment and it affects adversely photosynthetic activities. Due to these reasons, removal processes in industrial wastewater containing dyes come into prominence ecologically $[1,2,3,7]$. In the developed and developing countries, substantial environmental regulations have been implemented about pollutants released into receiving environment by the result of industrial activities [4]. Various industrial activities particularly the textile and dyeing industries are the main cause of pollution of the aquatic environment all over the world [5]. When the wastewater caused by industrial activity is released into the environment without being properly treated, even low amount of dyes results in esthetically undesired consequences [3]. By reason of the fact that the traditional method used for removal of dyes from wastewater causes additional pollution and the implementations are limited and require high cost; it raises the requirements of tending towards alternative methods such as biological systems which are effective and economic [6]. Various biomaterials such as bacteria, fungi and algae can connect to industrial and agricultural pollutants in wastewater and thanks to biosorption technique these organisms can be utilized in purification of contaminated water by the substances such as dyes and metals that cannot be easily resolved [4]. The first economic feasibility studies on applicability of biosorption technology show that this process provides significantly cost savings and that the recovery of heavy metals reduces additional cost [41]. Our purpose in this article is to provide an overview of the biosorption methods and microorganisms using and to collect the updated information.

\section{Dyes:-}

Dyes are chemical substances basically used to impart color to objects [1]. Most dyes are complex organic molecules and they should be resistant to physical and chemical exposure. Synthetic dyes are used extensively in the majority of today's technological areas such as especially textile industry, leather tanning, paper manufacturing, food industry, agricultural research and cosmetic. Dyes should be classified according to synthetic structure and their intention of use. However, although there are some common categories, the classification might vary pursuant to each country [7].

According to the chemical structure, dyes are divided into classes as Azo dyes, Aryl methane dyes, Acridine dyes, Anthraquinone dyes, Nitro dyes, Xanthine dyes, and Quinine-amine dyes etc. In the most of the industrial activity areas, azo dyes, the largest group of synthetic organic chemicals, has a wide range of uses [8].

According to the intended use; dyes might classify as acidic dyes, basic dyes, direct dyes, disperse dyes, food dyes, metal complexes, bleaching agents, pigments dyes, reactive dyes, mordant dyes, solvent dyes, sulfur dyes and vat dyes, etc. [7]. In industry, dyestuffs are mostly known by name that classified according to its intended use [9].

Unfortunately, there is no precise information on the amount of dye produced and released to the environment over the world [7].

\section{Biosorption:-}

Chemical's retention by microbial mass or adsorption is expressed as the biosorption [1]. In other words, the accumulation of effluents on cell surface or in the aqueous solution by biological materials is called the biosorption [10]. In biosorption process, the contaminants cling on the cell surface of organisms like live or dead bacteria, fungi, algae and lichen and or accumulate in cells [11]. For removing the color of the dye, these organisms' dead biomass might generally be used [12].

Cell surface has a negative charge in the presence of carbonyl, amino, hydroxy, and the phosphate group and it can adsorb a significant amount of cationic metals positively charged [Fig.1] [15]. 


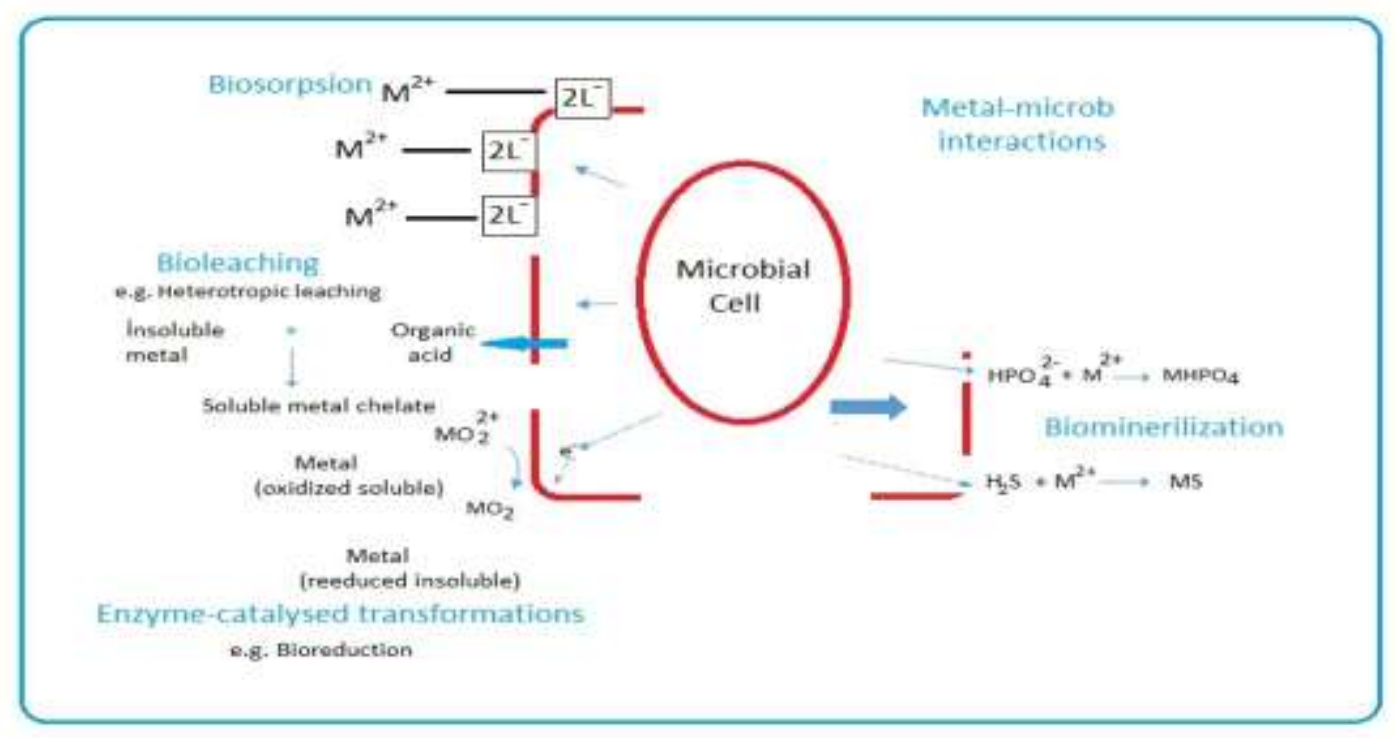

Figure 1:- Metal-microorganism interaction mechanisms [15].

Biosorption mechanisms are complex and not fully understood. A rich literature is available on biosorption modeling and mechanism in which microbial strain and specific elements are used. The existing biological ligand types separating metal, that state as alive or dead of biomass, target metal type, chemical, stereochemical and bonding characteristics, the presence of cation competing in the metal solution and $\mathrm{pH}$ are the qualities which play a key role in the characterization and control of biosorption mechanism [13].

The microbial biomass which receives or accumulates various pollutants involves primarily absorbing these chemicals on the cell surface and the uptake them from the environment by active or passive transport [12]. Current research shows that passive uptake is more applied than active in biosorption method. The reason is that living systems (active uptake) usually need additional nutrients; it increases biological oxygen demand in reaction output (BOI) and / or chemical oxygen demand (COD) [4].

\section{Factors Affecting The Biosorption:-}

Because of that the chemical structure of the dye is quite varied; the dyes' ability of interaction with microorganism depends on a number of factors such as the chemical structure, the characteristics of wastewater or dye solution and biomass structural specificity [7].

For example; solutions which have a high $\mathrm{pH}$ affects the capacity to biomass. Due to low $\mathrm{pH}, \mathrm{H}^{+}$ion concentration will be much more, therefore cell surface will hold $\mathrm{H}^{+}$ions rather than metal cation. The solution's chemical structure also affects the bacterial surface structure. When the $\mathrm{pH}$ increases, metal ions in the solution is getting be hydrolyzed [16]. Organic acids are adsorbed properly at low $\mathrm{pH}$ values, while the organic bases are adsorbed better at high $\mathrm{pH}[17]$.

Another factor affecting the biosorption is the temperature. High temperature increases the fluid's kinetic energy and surface activity so that the biosorption increases accordingly [4]. However, the high temperatures might damage physically biosorbents [17]. Due to passive or physical adsorption, heavy metal ions are connecting with weak bond to microorganisms, and then in high temperatures the bonds are broken, desorption might be occured because of adsorption's reversible characteristic, and it shows a decreasing effect to speed [16].

One of the factors that impact on the biosorption is the ionic strength and it affects the adsorption of dissolved substance in the biomass surface [18].

Biosorbent dosage is highly effective on biosorption amount and it is obtained a higher rate of elimination and a lower rate of removal effect with low biosorbent dose $[19,20]$. 
Because of the fact that the increase in biomass concentration causes the increase in biosorbent surface and binding area, the amount of dissolved solution generally increases [21]. However, biosorbent's amount of solution per unit weight reduces by biosorbents dose [16].

Biosorbent's size also plays an important role in the biosorption. Small-sized particles have a higher surface area, moreover, the short period of balancing time is an interest of biosorption. Also a biosorbent particles should be flexible enough to withstand the pressure to be applied during the regeneration cycle and the extreme cases [4].

Sometimes external film layer might affect the performance of the biosorption. Mass transfer resistance might be broken by appropriate rinsing process. By the rinsing, the thickness of the liquid film around the particles will be increased and film diffusion limits the speed. But if it is provided an adequate mix, film diffusion rate would move towards per diffusion point limiting the biosorption and resistance problem would be overcome $[4,10]$.

\section{Biosorbents:-}

Industrial wastewater contains a wide variety of dye but the largest group is azo dyes. In the past decade, it is seen that microorganisms such as bacteria, fungi, yeasts, algae and actinomycet are able to degrade azo dyes. The effectiveness of color removal process depends on compatibility and activity of organisms to be selected $[8,22]$.

\section{Bacteria:-}

In order to achieve a broad ingestion, bacteria to be used as nitrogen shredder require the ability to perform removal of a large number of dyes [22]. The most of research is focused on the tent on dyes removal of bacteria by biodegradation and the studies on the skills of decolorization by biodegradation attract less attention [23].

Won et al. (2005) defined Corynebacterium glutamicum biomass as a potential biosorbents in removal of Reactive Red 4 which is an anionic dye [24].

Busi et al. (2016) investigated the removal of lead and chromium heavy metals with Eriochrome black T, Acid red 26, Trypan blue by using dried Aeromonas hydrophila RC1 biomass. According to these data obtained, they reported that $A$. hydrophila $\mathrm{RC} 1$ biomass is the low-cost biomass which can be used in removal of dyes and heavy metals from wastewater [25].

In the study with the aim to determine the removal ability of sulfur dyes in synthetic dyes solution and the necessary optimum conditions, Nguyen et al. (2016) reported that Acidithiobacillus thiooxidans bacterial strain is able to adsorb synthetic sulfur blue 15 (SB 15) and it might be used as an extremely effective biosorbent for removal of SB 15 from the culture medium [26].

Sun et al. (2016) reported that Bacillus amyloliquefaciens biofilm is higly efficent for removal of contaminated wastewater by crystal violet (CV) and it can be used for this purpose. Moreover, they determined the maximum capacity for the $\mathrm{CV}$ adsorption as $582.41 \mathrm{mg} / \mathrm{g}$ and they stated that this value is the highest value identified so far for the adsorption CV [26].

Kim et al. (2015) showed that inanimate sorbents used in biosorption are effective as living sorbents at least and moreover, by most of the time they are more effective than alive biosorbents. They measured the ability to adsorb the Basic blue 3 cationic dye for Corynebacterium glutamicum, Bacillus cereus, C. glutamicum, Escherichia coli, B. megaterium, B. subtilis, B. pumilus, B. catenulatus, Exiguobacterium sp. biosorptions and they reported that $B$. Catenulatus's maximum absorption capacity is the highest [28].

\section{Fungi:-}

Many species of fungi have the ability of decolorisation of numerous dyes in active or inactive form [23].

In the literature it is mentioned that white rot fungi such as Phanerochaete chrysosporium has been widely used in decolorisation of textile wastewaters. Apart from white rot fungi, the fungi such as Aspergillus niger, Rhizopus arrhizus, Rhizopus oryzae are used in the removal of several dyes [24]. 
Chew and Ting (2016) reported for the first time that Trichoderma asperellum biomass which is a filamentous fungus can achieve the removal of triphenylmethane dyes [29].

For the study in which they used Phragmites australis as biosorbent and they utilized its form of both the raw and modified, Kankıliç et al. (2016) reported that Phragmites australis's maximum biosorption capacity is higher [30]. In the study that Gül et al. (2006) investigated the surfactant effect of a white fungus Trametes versicolor in textile dyes biosorpsiyon, they used Dodecyl trimethyl ammonium bromide (DTAB) as surfactant and they reported that Trametes versicolor increases substantially Everzol Black Biosorption [42].

Khelif et al. (2015) used Aspergillus alliaceus biomass in indigo biosorption which is mostly located in textile wastewaters and they reported that Aspergillus alliaceus could be implemented in the wastewater indigo biosorption [31].

It is not seen a comprehensive study on yeasts' ability of dye removal, but it is known that some yeast species can lyse industrial dyes by enzymatic pathway [23].

Ghaedi et al. (2013) studied on Saccharomyces cerevisiae biosorption skills on Brilliant green (BG) and Methylene blue (MB) dyes and they reported that Saccharomyces cerevisiae can start the biosorption in a short time as 5 minutes and a near value of neutral $\mathrm{pH}$ and they also reported that the removal rate for BG as \% 98-99.8 and for MB as \% 97.28-99.5 [32].

\begin{abstract}
Algea:-
Since Algea can live both at fresh-water and sea, they are considered as important biosorbent resources. Biosorbent capacity of Algea is related to relatively large surface area and high affinity. In addition to knowing that the cell wall properties of Algea have an important role for the biosorption, it is also known that during the algeal biosorption electrostatic attraction and complex formation events occur [33,34,35]. Functional groups on the membrane of Algea such as hydroxyl, carboxylate, amino and phosphate are considered as responsible from sequestration of contaminants at sewage [36].
\end{abstract}

Daneshvar et al. (2007) reported that, species of micro algea Cosmarium are potential "biosorbent" for biological decontamination of Malachite Green(MG) which is a triphenylmethane dye. They also reported that Algea species can decontaminate dyes and Cosmarium can decontaminate MG up to 89.1\% from their experimental results [37].

Kousha et al. (2012) made research about the decontamination of the dye Acid Black 1 (AB1) by brown micro algea species which live under the sea such as Nizamuddin zanardini, Sargassum glaucescens and Stoechospermum marginatum and the effects of the independent variables such as biomass dosage, dye concentration and $\mathrm{pH}$ of initial concentration on the decontamination of dye. They reported that the maximum dye decontaminations are $99.27 \%$ for Nizamuddin zanardini, 98.12\% for Sargassum glaucescens and 97.62\% for Stoechospermum marginatum [38].

Vijayaraghavan et al. (2016) examined the Methylene blue biosorption of Gracilaria corticata, which is a red algea, with functions of $\mathrm{pH}$ equilibrium, initial concentration and biosorbent concentration and they observed that the highest biosorption capacity is at $\mathrm{pH} 8.0$ [39].

\title{
Lichens:-
}

Lichens are the coexistence formed by fungi and photosynthetic algae and owing to these features, they are considered as significant potential resource of biosorbent in recent years [10].

In their work published in 2008, Uluözlü and his colleagues reported that Parmelina tiliaceae were used for aqueous iron and chromium biosorption in aqueous solutions and Parmelina tiliaceae could be used for the biological absorption of iron and chromium ions in aqueous solutions [43].

Purvis and his colleagues published in 2010 emphasized that Trapelia involuta could be used as biomass to protect against harmful effects of uranium [44].

Tay and colleagues in their work published in 2009 investigated the activity of a lichen, Ramalina fraxinea, in the biosorption of cadmium ions and reported that in the biosorption of cadmium ions, Ramalina fraxinea absorbed moderately cadmium compared to other biosorbents [45]. 


\section{Chitosan:-}

As being a derivative of kit, Chitosan is also the second most abundant biopolymer after cellulose in the world [40]. It is known that a plurality of dye especially anionic dyes can be removed by chitosan. This characteristic of chitosan is due to its polycationic structure [10].

In their work published in 2017, Tsai et al. investigated the absorption efficiency of chitosan modified with poly(poly(ethylene glycol) methyl ether methacrylate) (CTS-GMA-g-PPEGMA) and reported that the removal of Reactive Orange 16 dye, which is an azo dye, showed an increase in absorption ability by $33 \%$ compared to that of the main chitosan [46].

In their work published in 2017, Pereira et al. proposed that a combination of Chitosan / KSF-montmorillonite could be applied to remove anionic dyes from waste water even in acidic environments [47].

In their work published in 2016, Hosseini et al. investigated the ability of magnetic chitosan nanocomposites to absorption. Hosseini et al. in their work have reported that magnetic chitosan nanocomposites have excellent adsorptive properties and can be developed as economical and alternative adsorbents to treat paint wastewater [48].

\section{References:-}

1. Robinson, T., McMullan, G., Marchant, R., Nigam, P. Remediation of dyes in textile effluent: a critical review on current treatment technologies with a proposed alternative. Bioresource technology, 77(3), 2001, $247-255$.

2. Platin, S. Beyaz Çürükçül Funguslar İle Tekstil Boyarmaddelerin Renginin Giderimi. Doktora Tezi, Eskisehir Osmangazi Üniversitesi. 2004.

3. Kocaer, F.O., ve Alkan, U. Boyar madde içeren tekstil atiksularinin aritim alternatifleri. Uludag Üniversitesi Mühendislik Mimarlik Fakültesi Dergisi,7, 2002, 47-55.

4. Vijayaraghavan, K., and Yun, Y.S. Bacterial biosorbents and biosorption. Biotechnology advances, 26(3), 2008, 266-291.

5. Ito, T., Adachi, Y., Yamanashi, Y., Shimada, Y. Long-term natural remediation process in textile dye-polluted river sediment driven by bacterial community changes. Water research, 100, 2016, 458-465.

6. Khadijah, O., Lee, K. K., Abdullah, M. F.F. Isolation, screening and development of local bacterial consortia with azo dyes decolourising capability. Malaysian Journal of Microbiology, 5(1), 2009,25-32.

7. Ramachandra, T., Ahalya, N., Kanamadi, R. Biosorption: techniques and mechanisms. CES Technical Report 110. Centre for Ecological Sciences, Indian Institute of Science Bangalore. 2005.

8. Rauf, M.A., and Ashraf, S.S. Survey of recent trends in biochemically assisted degradation of dyes. Chemical engineering journal, 209, 2012, 520-530.

9. Çelebi, M. Tekstil atık sularında boyaların biyobozunma ile giderilmesi (Doctoral dissertation, YTÜ Fen Bilimleri Enstitüsü). 2013.

10. Hamutoğlu, R., Dinçsoy, A. B., Cansaran-Duman, D., Aras, S. Biyosorpsiyon, adsorpsiyon ve fitoremediasyon yöntemleri ve uygulamaları. Türkiye Hijyen ve Deneysel Biyoloji Dergisi, 2012, 69, 69.

11. Sternberg, S.P., and Dorn, R.W. Cadmium removal using Cladophora in batch, semi-batch and flow reactors. Bioresource Technology, 81(3), 2002, 249-255.

12. 109G083 No’lu Tubitak Kamag Projesi. Boyar Madde İçeren Atıksu Arıtma Tesislerinin İşletilmesine Yönelik El Kitabi. 2013, 67-79. Ankara.

13. Tsezos, M., Remoundaki, E., Hatzikioseyian, A. Biosorption-principles and applications for metal immobilization from waste-water streams. Proceedings of EU-Asia Workshop on Clean Production and Nanotechnologies, 2006, 23-33.

14. Hussein, H., Ibrahim, S. F., Kandeel, K., Moawad, H. (). Biosorption of heavy metals from waste water using Pseudomonas sp. Electronic Journal of Biotechnology, 7(1), 2004, 30-37.

15. Lloyd, J. R. Bioremediation of metals; the application of micro-organisms that make and break minerals. Interactions, 2, 2002, M2.

16. Bozanta, E., ve Ökmen, G. Biyosorpsiyon ve mikroorganizmalar. Türk Bilimsel Derlemeler Dergisi, 4(2), 2011, 69-77.

17. Mameri, N., Boudries, N., Addour, L., Belhocine, D., Lounici, H., Grib, H., Pauss, A. Batch zinc biosorption by a bacterial nonliving Streptomyces rimosus biomass. Water research, 33(6), 1999, 1347-1354.

18. Borrok, D., Turner, B. F., Fein, J. B. A universal surface complexation framework for modeling proton binding onto bacterial surfaces in geologic settings. American Journal of Science, 305(6-8), 2005, 826-853. 
19. Aksu, Z., and Çağatay, Ş.Ş. Investigation of biosorption of Gemazol Turquise Blue-G reactive dye by dried Rhizopus arrhizus in batch and continuous systems. Separation and Purification Technology, 48(1), 2006, 2435.

20. Vijayaraghavan, K., Palanivelu, K., Velan, M. Biosorption of copper (II) and cobalt (II) from aqueous solutions by crab shell particles. Bioresource technology, 97(12), 2006, 1411-1419.

21. Esposito, A., Pagnanelli, F., Lodi, A., Solisio, C., Veglio, F. Biosorption of heavy metals by Sphaerotilus natans: an equilibrium study at different pH and biomass concentrations. Hydrometallurgy, 60(2), 2001, 129141.

22. Chen, K. C., Wu, J. Y., Liou, D. J., Hwang, S. C. J. Decolorization of the textile dyes by newly isolated bacterial strains. Journal of Biotechnology, 101(1), 2003, 57-68.

23. Srinivasan, A., and Viraraghavan, T. Decolorization of dye wastewaters by biosorbents: a review. Journal of environmental management, 91(10), 2010, 1915-1929.

24. Won, S. W., Choi, S. B., Yun, Y. S. Interaction between protonated waste biomass of Corynebacterium glutamicum and anionic dye Reactive Red 4. Colloids and Surfaces A: Physicochemical and Engineering Aspects, 262(1), 2005, 175-180.

25. Busi, S., Chatterjee, R., Rajkumari, J., Hnamte, S. Ecofriendly biosorption of dyes and metals by bacterial biomass of Aeromonas hydrophila RC1. Journal of Environmental Biology, 37(2), 2016, 267.

26. Nguyen, T. A., Fu, C. C., Juang, R. S. Biosorption and biodegradation of a sulfur dye in high-strength dyeing wastewater by Acidithiobacillus thiooxidans. Journal of Environmental Management, 182, 2016, $265-271$.

27. Sun, P., Hui, C., Wang, S., Wan, L., Zhang, X., Zhao, Y. Bacillus amyloliquefaciens biofilm as a novel biosorbent for the removal of crystal violet from solution. Colloids and Surfaces B: Biointerfaces, 139, 2016, 164-170.

28. Kim, S. Y., Jin, M. R., Chung, C. H., Yun, Y. S., Jahng, K. Y., Yu, K. Y. Biosorption of cationic basic dye and cadmium by the novel biosorbent Bacillus catenulatus JB-022 strain. Journal of bioscience and bioengineering,119(4), 2015, 433-439.

29. Chew, S. Y., and Ting, A. S. Y. Common filamentous Trichoderma asperellum for effective removal of triphenylmethane dyes. Desalination and Water Treatment, 57(29), 2016, 13534-13539.

30. Kankılıç, G. B., Metin, A. Ü., Tüzün, İ. Phragmites australis: An alternative biosorbent for basic dye removal. Ecological Engineering, 86, 2016, 85-94.

31. Khelifi, E., Touhami, Y., Bouallagui, H., Hamdi, M. Biosorption of indigo from aqueous solution by dead fungal biomass Aspergillus alliaceus. Desalination and Water Treatment, 53(4), 2015, 976-984.

32. Ghaedi, M., Hajati, S., Barazesh, B., Karimi, F., Ghezelbash, G. Saccharomyces cerevisiae for the biosorption of basic dyes from binary component systems and the high order derivative spectrophotometric method for simultaneous analysis of Brilliant green and Methylene blue. Journal of Industrial and Engineering Chemistry, 19(1), 2013, 227-233.

33. Dönmez, G., and Aksu, Z. Removal of chromium (VI) from saline wastewaters by Dunaliella species. Process Biochemistry, 38(5), 2002, 751-762.

34. Tien, C. J. Biosorption of metal ions by freshwater algae with different surface characteristics. Process Biochemistry, 38(4), 2002, 605-613.

35. Şatiroğlu, N., Yalcınkaya, Y., Denizli, A., Arıca, M. Y., Bektaş, S., Genç, Ö. Application of NaOH treated Polyporus versicolor for removal of divalent ions of Group IIB elements from synthetic wastewater. Process Biochemistry, 38(1), 2002, 65-72.

36. Özer, A., Akkaya, G., Turabik, M. The removal of Acid Red 274 from wastewater: combined biosorption and biocoagulation with Spirogyra rhizopus. Dyes and pigments, 71(2), 2006, 83-89.

37. Daneshvar, N., Ayazloo, M., Khataee, A. R., Pourhassan, M. Biological decolorization of dye solution containing Malachite Green by microalgae Cosmarium sp. Bioresource technology, 98(6), 2007, 1176-1182.

38. Kousha, M., Daneshvar, E., Dopeikar, H., Taghavi, D., Bhatnagar, A. Box-Behnken design optimization of Acid Black 1 dye biosorption by different brown macroalgae. Chemical Engineering Journal, 179, 2012, 158168.

39. Vijayaraghavan, J., Bhagavathi Pushpa, T., Sardhar Basha, S. J., Jegan, J. Isotherm, kinetics and mechanistic studies of methylene blue biosorption onto red seaweed Gracilaria corticata. Desalination and Water Treatment, 57(29), 2016, 13540-1354

40. Guibal, E., Sweeney, N. V. O., Vincent, T., Tobin, J. M. Sulfur derivatives of chitosan for palladium sorption. Reactive and Functional Polymers, 50(2), 2002, 149-163.

41. Volesky, B., Naja, G. Biosorption: application strategies. In 16th International Biohydrometallurgy Symposium, 2005, (pp. 25-29). 
42. Gül, Ü. D., Silah, H., Akbaş, H., Has, M. The effect of surfactant on pollutant biosorption of Trametes versicolor. International Conference On Advances in Natural and Applied Sciences: Icanas 2016 (Vol. 1726, No. 1, p. 020031). AIP Publishing.

43. Uluozlu, O. D., Sari, A., Tuzen, M., Soylak, M. Biosorption of $\mathrm{Pb}$ (II) and Cr (III) from aqueous solution by lichen (Parmelina tiliaceae) biomass. Bioresource Technology, 99(8), 2008, 2972-2980.

44. Purvis, O. W., Bailey, E. H., McLean, J., Kasama, T., Williamson, B. J. Uranium biosorption by the lichen Trapelia involuta at a uranium mine. Geomicrobiology Journal, 21(3), 2004, 159-167.

45. Tay, T., Candan, M., Erdem, M., Çimen, Y., Türk, H. Biosorption of Cadmium Ions from Aqueous Solution Onto Non-living Lichen Ramalina fraxinea Biomass. CLEAN-Soil, Air, Water, 37(3), 2009, 249-255.

46. Tsai, B., Garcia-Valdez, O., Champagne, P., Cunningham, M. F. Poly (Poly (Ethylene Glycol) Methyl Ether Methacrylate) Grafted Chitosan for Dye Removal from Water.Processes, 5(1), 2017, 12.

47. Pereira, F. A., Sousa, K. S., Cavalcanti, G. R., França, D. B., Queiroga, L. N., Santos, I. M. Jaber, M. Green biosorbents based on chitosan-montmorillonite beads for anionic dye removal. Journal of Environmental Chemical Engineering, 5(4), 2017, 3309-3318.

48. Hosseini, F., Sadighian, S., Hosseini-Monfared, H., Mahmoodi, N. M. Dye removal and kinetics of adsorption by magnetic chitosan nanoparticles. Desalination and Water Treatment, 57(51), 2016, 24378-24386. 